\title{
Changes in the nutritional composition of okra fruit and seed during early development
}

\author{
Tito E. Cachero and Beatriz S. Belonias
}

This study investigated the changes in nutrient content of the fruit and seed of Okra or Lady Finger during development and maturation. Okra flowers were tagged at flower opening or anthesis. Sample fruits (technically called capsules) that developed from the tagged flowers were collected at random at $3,6,9,12,15,18,21$ and 24 days after anthesis (DAA). The pericarp and seed samples were oven-dried and ground to a powdered form and analyzed for chlorophyll, sugar, starch, crude protein and crude fiber content using standard procedures. Chlorophyll and crude fiber content were strongly positively correlated with fruit age, being lowest in the pericarp of young fruits and highest in older fruits. Sugar, starch and protein content were all negatively correlated with fruit age. They were highest in the pericarp of young 3-day old fruits and steadily decreased with maturity, reaching lowest levels at day 24 . In the seeds, protein and starch contents were weakly correlated with fruit maturity. Throughout seed development, sugar remained relatively low while starch and protein content remained high. Based on the results, okra fruits are best harvested as fresh green vegetable at 9 DAA. At this stage, the fruits are succulent, less fibrous and are rich in proteins and carbohydrates. Although much younger fruits also have high nutrient content, they are too small in size, so harvesting them at this stage would not be practical and profitable.

Keywords: okra, capsule, chlorophyll, nutrients, anthesis

\section{INTRODUCTION}

Fruit quality and harvestability are commonly evaluated based on measurement of size, weight and physical attributes such as color, firmness and moisture content, or based on sensory attributes such as taste, aroma, texture and appearance. Another way of determining optimum fruit harvest maturity is to

'Department of Biological Sciences, Visayas State University, Baybay City-6521, Leyte, Philippines

\footnotetext{
*Corresponding Author. Address: Department of Biological Sciences, Visayas State University, Baybay City-6521, Leyte, Philippines; Email: beatrizbelonias@vsu.edu.ph
} 
analyze the changes in the nutrient content of the fruit and the seeds at different stages of development to ensure that the nutritional quality of the fruits at harvest are at its best (Taiz and Zeiger 2006). Previous studies have shown that as a fruit develops towards maturity, concentrations of chemical compounds such as starch, sugar, protein, chlorophyll and fiber dramatically change, resulting to changes in fruit texture, flavor and firmness (Brummel 2013, Kim et al 2003, Patil 2015, Miccolis and Salveit 1991).

Okra or Lady Finger (Abelmoschus esculentus (L.) Moench) produces fingershaped fruits, which are technically called capsules (Chauhan 2012). The edible green fruits are harvested and consumed as vegetable. It can be boiled, fried, steamed, grilled, battered or eaten fresh. Powdered seeds can be an excellent coffee substitute. Okra is high in fiber and rich in vitamins and minerals, such as calcium, vitamin $\mathrm{C}$ and folate. It is used to treat genito-urinary disorders, spermatorrhoea, chronic dysentery, ulcers and hemorrhoids. Although its slimy mucilage makes the fruit infamous, this mucilage can be used to treat syphilis, cuts, wounds and boils and as plasma replacement (Kumar 2012). The whole plant can be processed into rope and paper (Mandal 2014), and the flower buds and petals can be consumed as food in times of food shortage (Lamont 1999).

In an earlier publication, Cachero and Belonias (2017) described the development of the fruits or capsules and seeds of okra. The okra plants flowered 48 days after sowing. The flowers opened from 6:00 to around 10:00 in the morning. A very small fruit with tiny seeds became visible one day after anthesis which rapidly grew in size (more in length than in diameter) and weight in the next 9 days after which growth gradually slowed down reaching full mature size at day 24 . Growth in weight of the fruit and the seeds followed a double sigmoidal pattern. Moisture content in young fruits and seeds was high but gradually decreased with fruit age. Conversely, dry matter content in young fruits and seeds was low but increased with maturity. Young fruits were more rounded in diameter and were more hairy but became increasingly ribbed and smooth with age.

Generally, most studies had been done on okra as food and non-food applications. However, few studies had been done to examine the changes in nutritional composition of the okra fruit and seed during early development. Such data would serve as index to define the optimal stage of maturity for harvest and to ensure good postharvest quality of the crop.

\section{MATERIALS AND METHODS}

\section{Field Planting}

An area of $10 \mathrm{~m} \times 10 \mathrm{~m}^{2}$ in size was prepared. Seeds of Okra (var. 'Smooth Green') were sown in rows at three seeds per hill. The distance between rows was one meter and the distance between hills was $64 \mathrm{~cm}$. One tbsp. of complete fertilizer (14-14-14) per hill was applied at sowing, and one-half tbsp. of urea (46-0-0) was side-dressed one month after planting. The seeds germinated three days after sowing and started to flower 48 days thereafter.

\section{Experiment Design}

Flowers were tagged at flower opening or anthesis. Sample fruits (technically called capsules) that developed from the tagged flowers were collected at $3,6,9,12$, 
$15,18,21$ and 24 days after anthesis (DAA). The experiment was done in Completely Randomized Design (CRD) with fruit age expressed as number of days from anthesis, as treatments and in three replications. Fruit ages were 3, 6, 9, 12, 15, 18, 21 and 24 days after anthesis (DAA). Figures 1 and 2, adopted from Cachero and Belonias (2017), show the okra fruit and seed at the different stages of development used in this study.

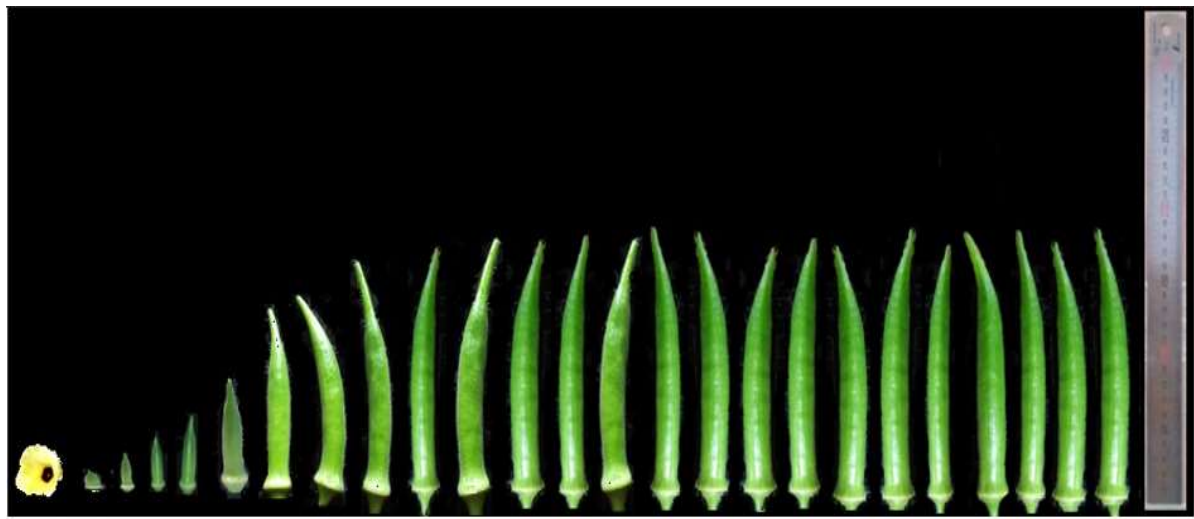

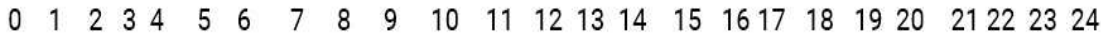
Days After Anthesis

Figure 1. Okra fruit at different stages of development (Cachero and Belonias 2017)

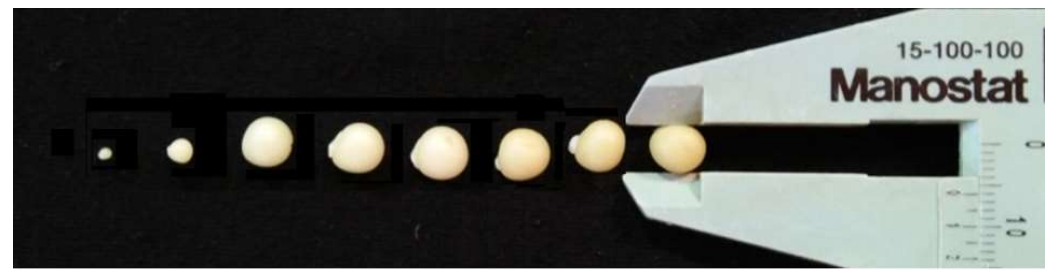

$\begin{array}{llllllll}3 & 6 & 9 & 12 & 15 & 18 & 21 & 24\end{array}$

Days After Anthesis

Figure 2. Okra seed at different stages of development (Cachero and Belonias 2017)

\section{Data Collection}

The pericarp and seed samples were oven-dried and ground to a fine powder and analyzed for sugar, starch, crude protein and crude fiber using standard procedures as described by Cagampang and Rodriquez (1980). Chlorophyll content was analyzed using a portable digital chlorophyll meter SPAD 502 Plus (Konica Minolta Japan).

\section{Statistical Analysis}

The Pearson Product Moment Correlation Coefficient using SPSSv.16.0 was used to test relationships between the chemical parameters and fruit age with the $1 \%$ level of significance. 


\section{RESULTS AND DISCUSSION}

\section{Chemical Changes in the Pericarp}

\section{Chlorophyll content}

Young okra fruits were light green in color and became increasingly deep green with age. Figure 3 shows a steady rise in chlorophyll content of the fruits with increasing maturity. The youngest 3-day old fruits contained 5.36 SPAD units of chlorophyll which increased by approximately 4 SPAD units in the next 6 days and continued to rise by 2-3 SPAD by the $15^{\text {th }}$ day reaching a maximum of 22.45 SPAD units at 24 DAA. There was a high positive correlation between chlorophyll content and fruit age $(r=0.972)$ which means chlorophyll content increases with fruit age.

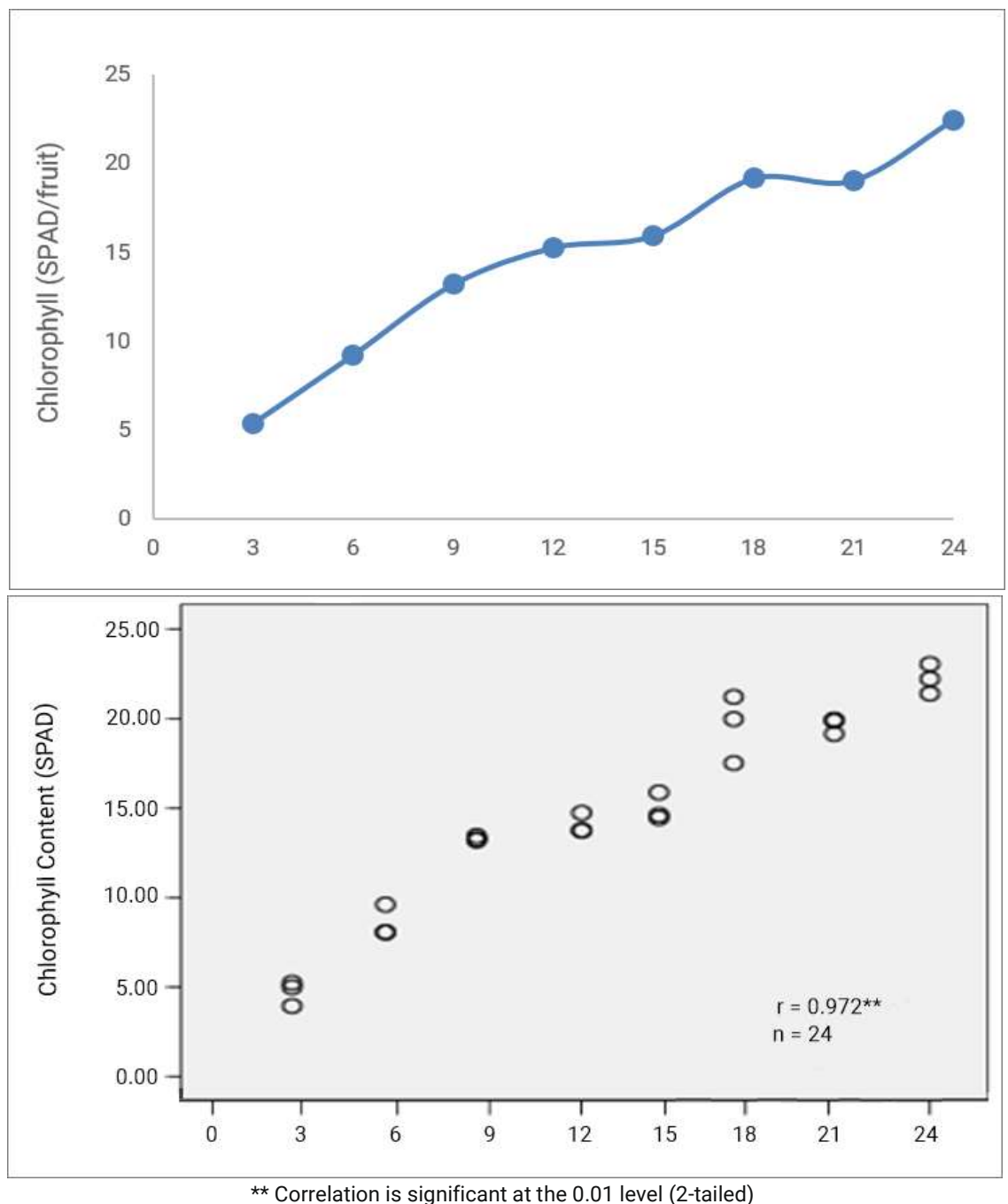

Figure 3. Changes on the chlorophyll content of the okra fruit pericarp during development from $3^{\text {rd }}$ to the $24^{\text {th }}$ DAA 
The green pigment chlorophyll and its cohorts of specialized enzymes transform the photons of light through its action on $\mathrm{CO}_{2}$ and $\mathrm{H}_{2} \mathrm{O}$ into sugars and organic matter. It is abundant in the leaves and needs light and protochlorophyllide oxidoreductase enzyme for its continued biosynthesis (Cutler 2007). Its presence in the fruit could boost and aid the expanded leaves in harvesting photosynthetically active radiation (PAR) thus increasing photosynthetic capacity of the plant. Therefore, the smaller and younger the fruit is, the lower the radiation interception; the lesser the chlorophyll synthesized, the lesser its productivity. As the fruit matures, it becomes bigger and longer providing a larger surface area for light interception; the more it becomes chlorophyll-rich, the higher its biomass accumulation. Furthermore, the hairs or trichomes in a younger fruit reflect and refract light which in turn masks the chlorophyll in it making it less photosynthetically functional (Cutler 2007).

\section{Sugar and Starch Content}

Sugar and starch content in the fruit pericarp were high in young fruits but continually declined with increasing maturity (Figures $4 a-4 b)$. This was shown by the highly significant negative correlation between sugar and fruit age $(r=-0.789)$ as well as starch content and fruit age $(r=-0.616)$ (Figure 4a.2 and b.2). Sugar content started high in younger pericarp $(13.81 \%)$ at 9 DAA and dropped to $5.33 \%$ in the oldest pericarp at 24 DAA. Meanwhile, starch content was highest at $14.06 \%$ at 3 DAA and decreased to $8.9 \%$ at 24 DAA. The high sugar content in young fruits is due to the fact that young growing organs are actively metabolizing and are thus very strong sinks for photoassimilates. With age, some of these sugars are converted into complex carbohydrates like starch and is translocated to the developing seeds for storage in the endosperm.

The important facet of any fruit development is the plant sugar unloading from vegetative source to reproductive sink. As such there is always plentiful deposition and accumulation of carbohydrates like starch, sucrose, fructose and other sugars in fruits fleshy pericarp. Aside from the fact that enlarging fruit requires carbohydrates to sustain cell division, enlargement and tissue differentiation, this plentiful carbohydrate deposits in the fleshy pericarp becomes the principal requirements for seed development at the later stage of development. It provides temporary storehouse for the growing seeds. As the fruit matures the fleshy pericarp carbohydrate food reserves are translocated and transformed into lipids and proteins and starch in the seeds (Brummel 2013). This might explain why there was a synchronized decline and changes in the chemical content of the pericarp with fruit age.

\section{Protein Content}

As shown in Figure 4c, protein content in the pericarp declined with fruit maturity as shown by the strong inverse correlation $(r=-0.789)$ between protein content and fruit age. Protein content started highest at 3 DAA with $18.14 \%$, and steadily declined reaching the lowest amount of $7.49 \%$ at 24 DAA. Young organs like fruits usually synthesize a higher amount of proteins, especially structural and enzymatic proteins for their active metabolism. Protein synthesis declines as metabolism decreases with age. 


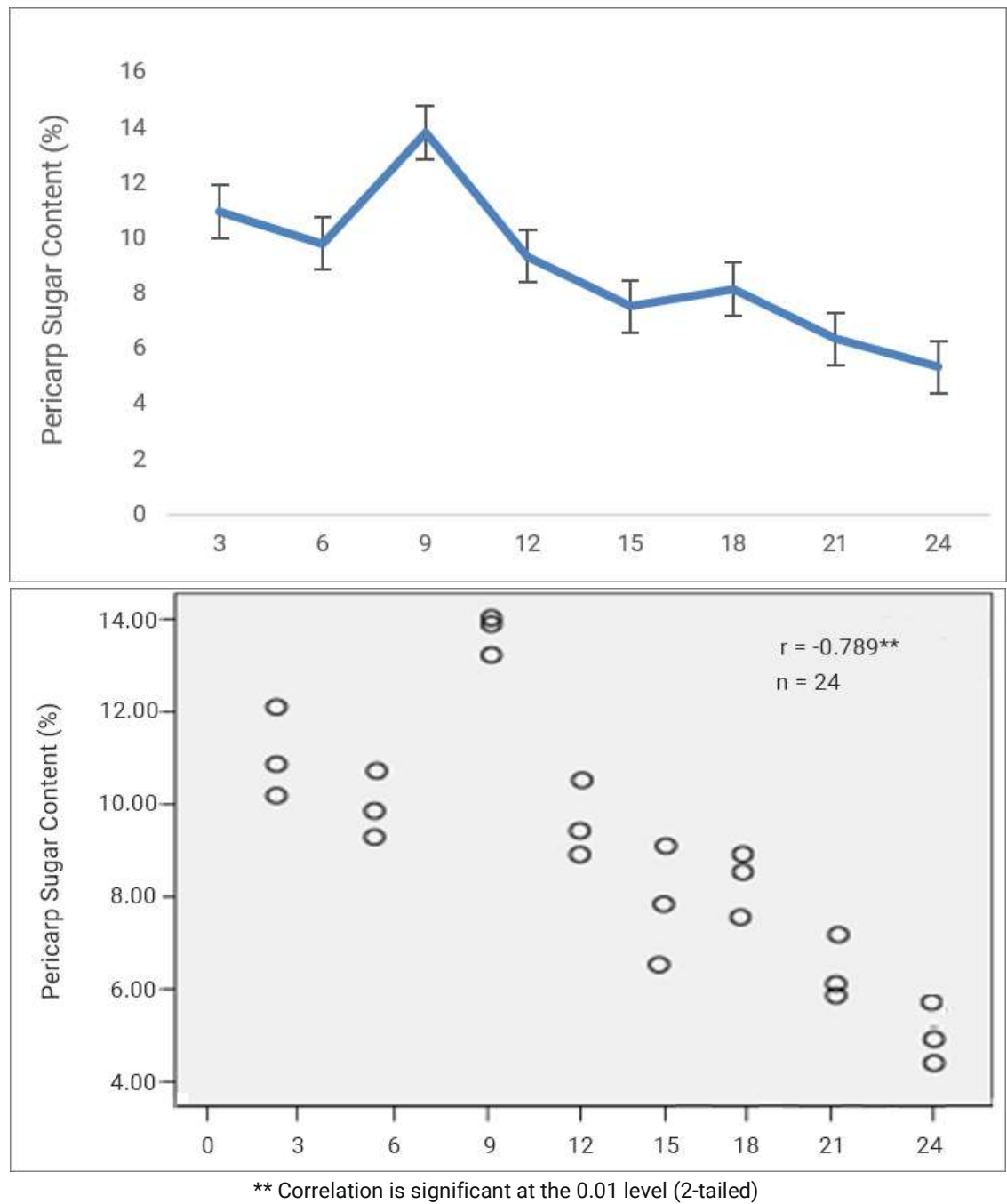

Figure 4a. Changes in sugar content of the okra fruit pericarp during development from the $3^{\text {rd }}$ to the $24^{\text {th }}$ DAA

Johnson (2005) explained that in mitotically dividing cells, the $G_{1}$ and $G_{2}$ phases of the cell cycle accumulate large amount of cyclin protein that binds to Cyclindependent kinases (Cdks) to activate cellular enzymes which phosphorylate the Mitosis-Promoting Factors (MPF). The activated MPF triggers mitochondria, chloroplasts, chromosomes and other organelles to replicate and signals the cell to enter Mitosis (M phase) and cytokinesis. As mitosis ends, similar MPF activates other proteins to degrade cyclin causing negative feedback to halt MPF production lowering cyclin protein in non-dividing mature tissues. This means lots of structural and enzymatic proteins are produced in younger organs and tissues and declines with cell specialization. Presumably, the continuous fall in protein as the pericarp matures could also be a consequence of the continuous chemical draining effect of seed development in the pericarp's food reserves. In this way, translocation of assimilates shifts in favor of seed nourishment as it grows older (Umamahesh 2005). 


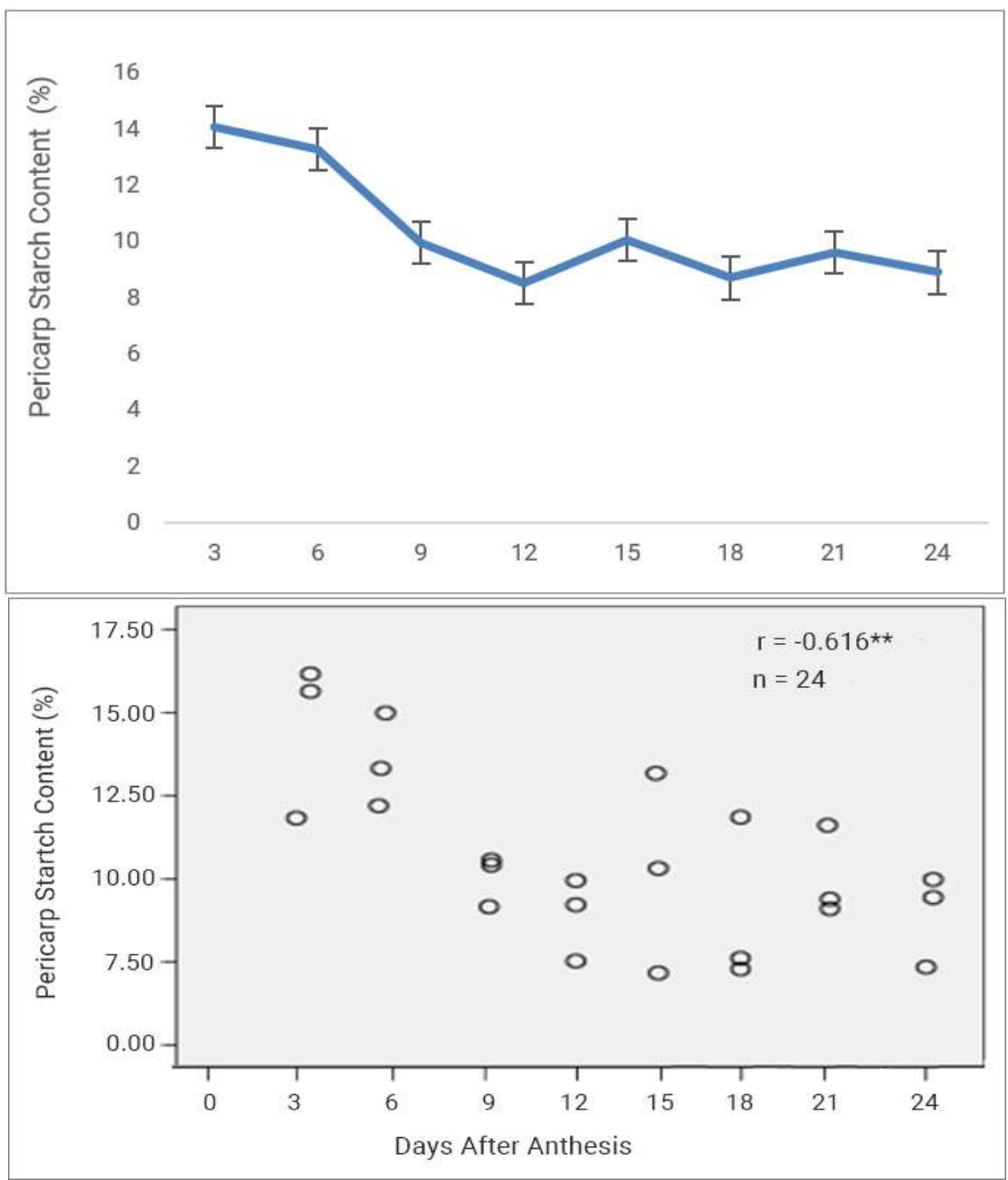

** Correlation is significant at the 0.01 level (2-tailed)

Figure 4b. Changes in starch content of the okra fruit pericarp during development from the $3^{\text {rd }}$ to the $24^{\text {th }}$ DAA

\section{Fiber Content}

There was an increasing formation of fibers in the pericarp tissues with fruit age (Figure 4d), and it is manifested by a highly strong direct correlation coefficient of $r=0.830$ (Figure $4 \mathrm{~d} 2$ ). The highest fiber content was obtained at the $18^{\text {th }}$ day with $51.65 \%$. The youngest fruits aged 3 and 6 days old had the lowest fiber content of only $16.17-16.79 \%$.

Fibers and sclereids are specialized cells designed for additional protection and strengthening support for material movement and transport in plants. They are found in close association with phloem and xylem tissues. Since younger fruits 
have smaller, tightly packed cells a simple diffusion of materials and vacuolation process might be enough to make the cells nourished and turgid. As the fruit matures, vascular tissues differentiate; the fruit becomes larger, bulkier and elongated so much so that materials are needed to be efficiently transported in bulk flow; increasing fibrousness in phloem and xylem provides the mechanical aid to facilitate this transport process (Taiz and Zeiger 2006).

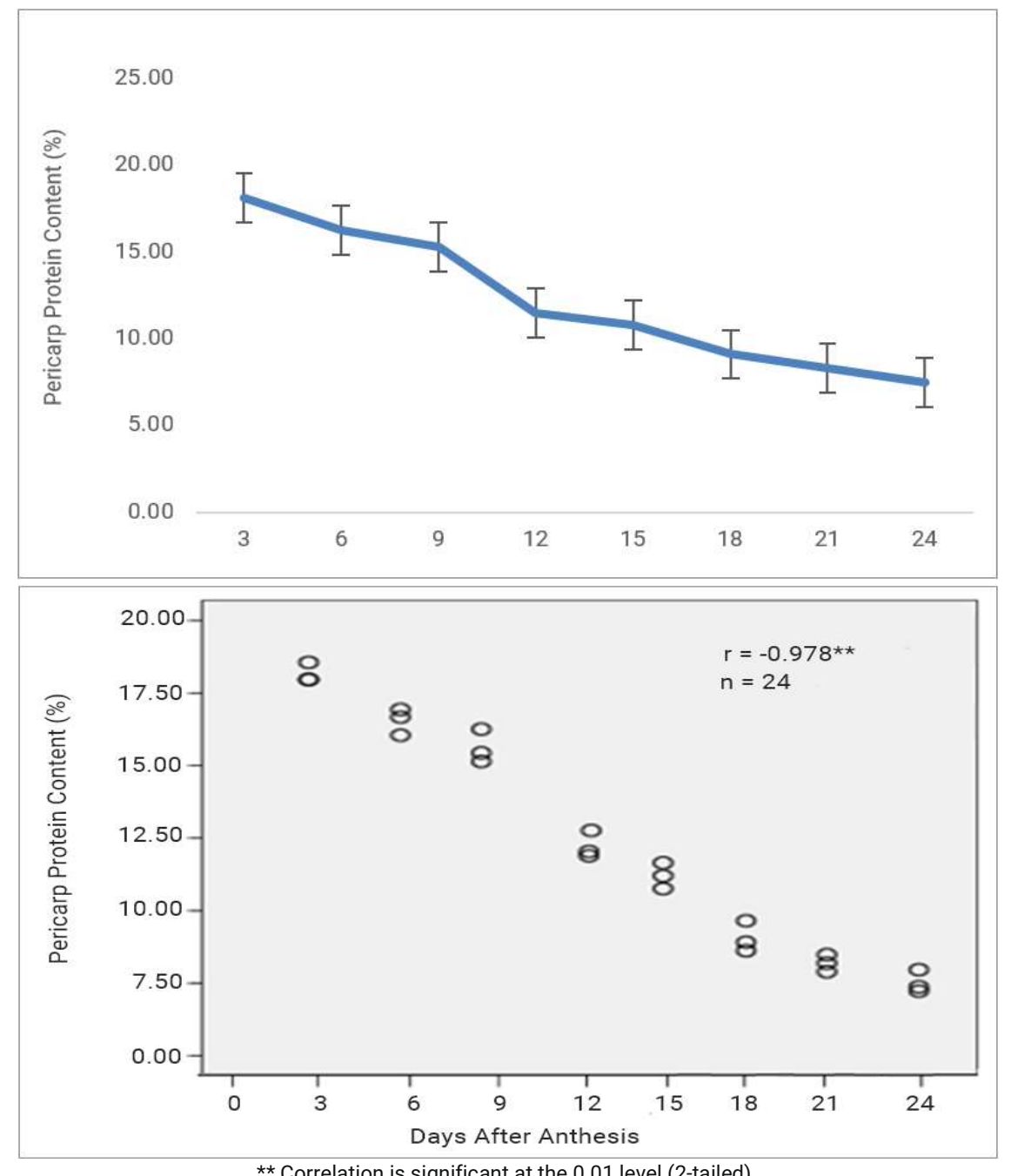

** Correlation is significant at the 0.01 level (2-tailed)

Figure 4c. Changes in protein content of the okra fruit pericarp during development from the $3^{\text {rd }}$ to the $24^{\text {th }}$ DAA 

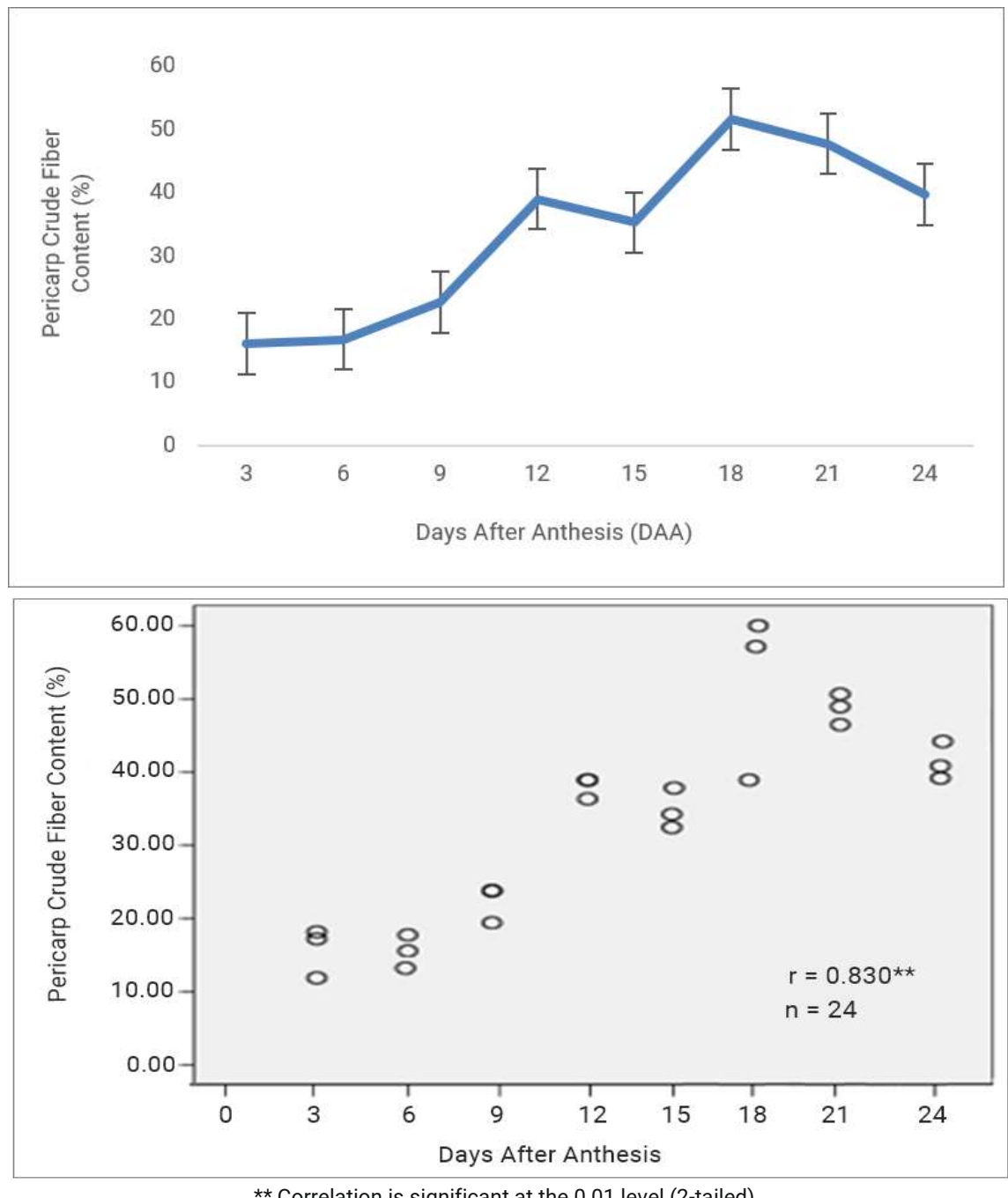

Figure $4 \mathrm{~d}$. Changes in crude fiber content of the okra fruit pericarp during development from the $3^{\text {rd }}$ to the $24^{\text {th }}$ DAA

\section{Chemical Changes in Seed}

\section{Sugar and starch content}

There was no remarkable increase in sugar and starch content in the seeds with increasing maturity (Figure $5 a-5 b$ ). Results seemed to show some increase in these substances with fruit age, but there was a weak correlation of $r=0.254$ and $r=0.409$ for sugar and starch content, respectively. Young seeds usually contain low amount of sugars due to the high consumption of sucrose and glucose in the metabolically active cells of the pericarp; thus, less sugar is available for 
assimilation to the young seeds. In older seeds, these simple sugars are converted into complex carbohydrates like starch which accumulates in the endosperm as food reserve (Johnson 2005). In the study of Wu et al (2008) on the ultrastructure of the pericarp and seed capsule cells in the developing walnut fruit, they observed that the nutrients in the fleshy pericarp parenchyma cells are transported in vesicles into the parenchyma tissue of the seed coat via transfer cells of the seed coat (mesosperm) having numerous mitochondria. Energy source from sugar is spent for this action. This might also explain why sugar content throughout the seed development remains relatively low.

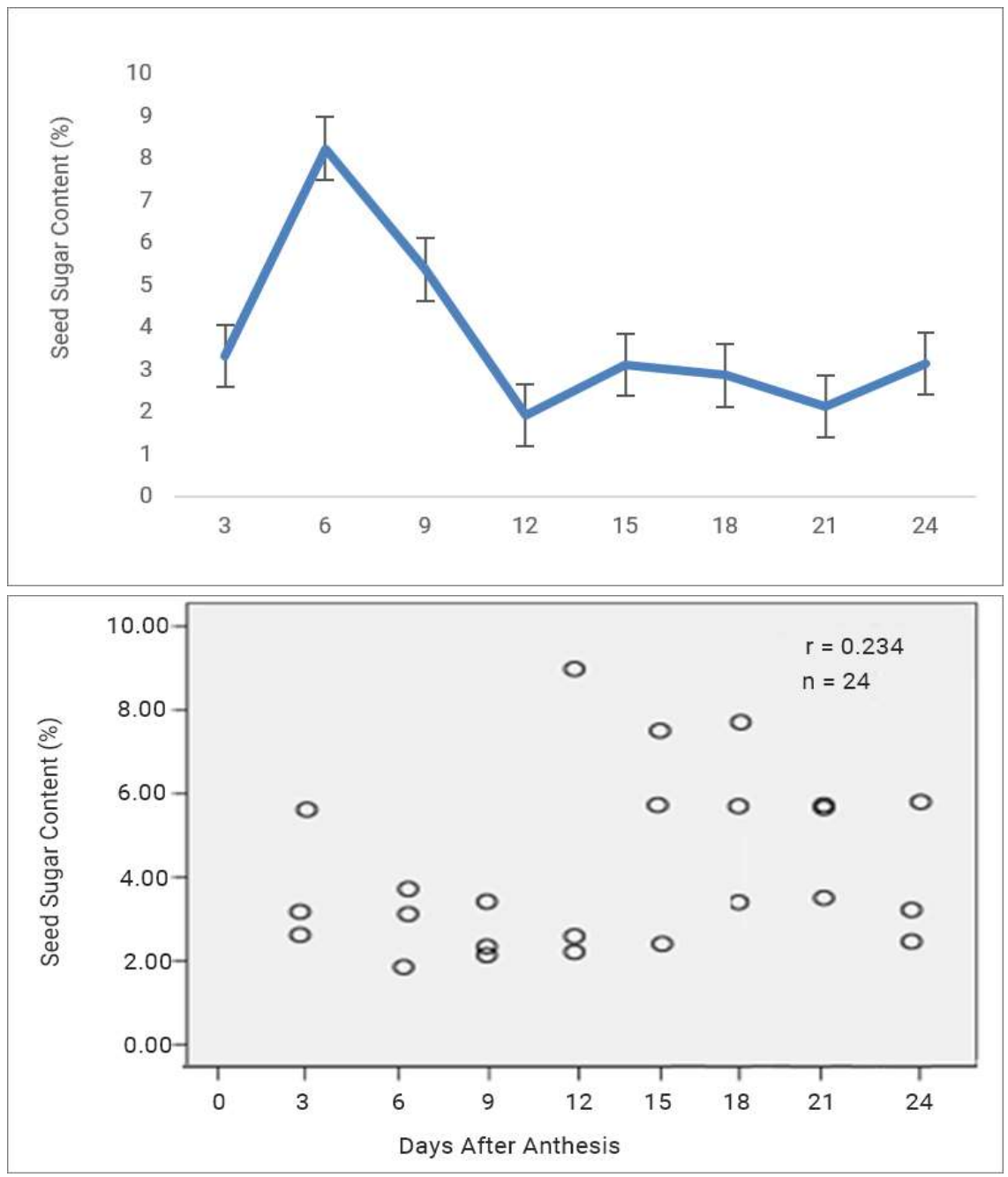

** Correlation is significant at the 0.01 level (2-tailed)

Figure 5a. Changes in sugar content of the okra fruit pericarp during development from the $3^{\text {rd }}$ to the $24^{\text {th }}$ DAA 


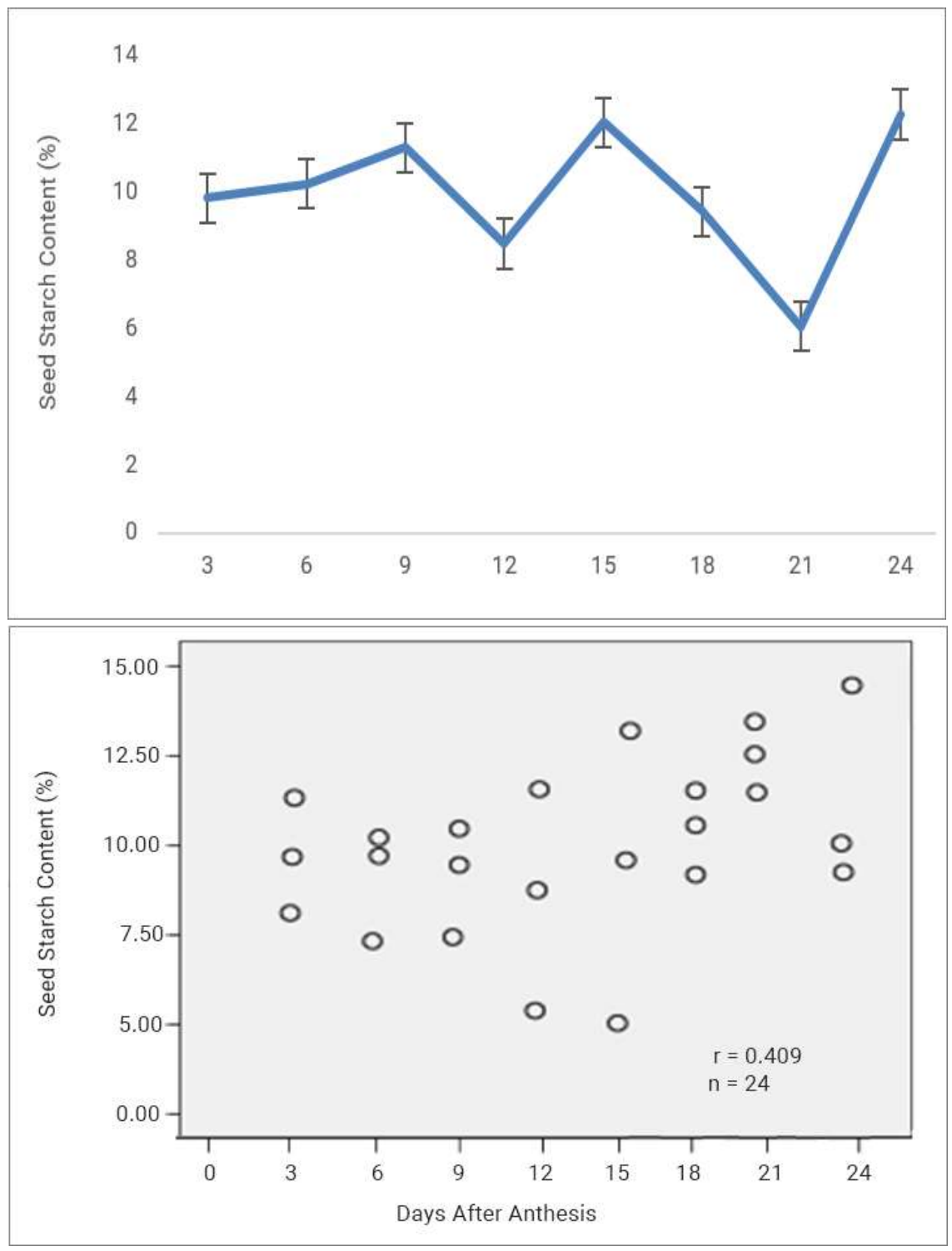

** Correlation is significant at the 0.01 level (2-tailed)

Figure $5 \mathrm{~b}$. Changes in starch content of the okra fruit pericarp during development from the $3^{\text {rd }}$ to the $24^{\text {th }}$ DAA

\section{Protein Content}

There was a weak correlation of 0.294 between protein and fruit age. This means protein content in seeds remained high from the start of seed development until the $24^{\text {th }}$ DAA. Figure $5 \mathrm{c}$ is shows equally highest percent in protein content throughout the early seed maturation. 
When the seed is younger, the proteins are probably of the enzymatic type because they are metabolically active. Synthesized hormonal protein type such as auxin and gibberellin might also constitute in the rapidly growing seed. When the seed is oldest, it is probably of storage protein type due to the fact that it is nearing seed dormancy stage (Reece 2014).
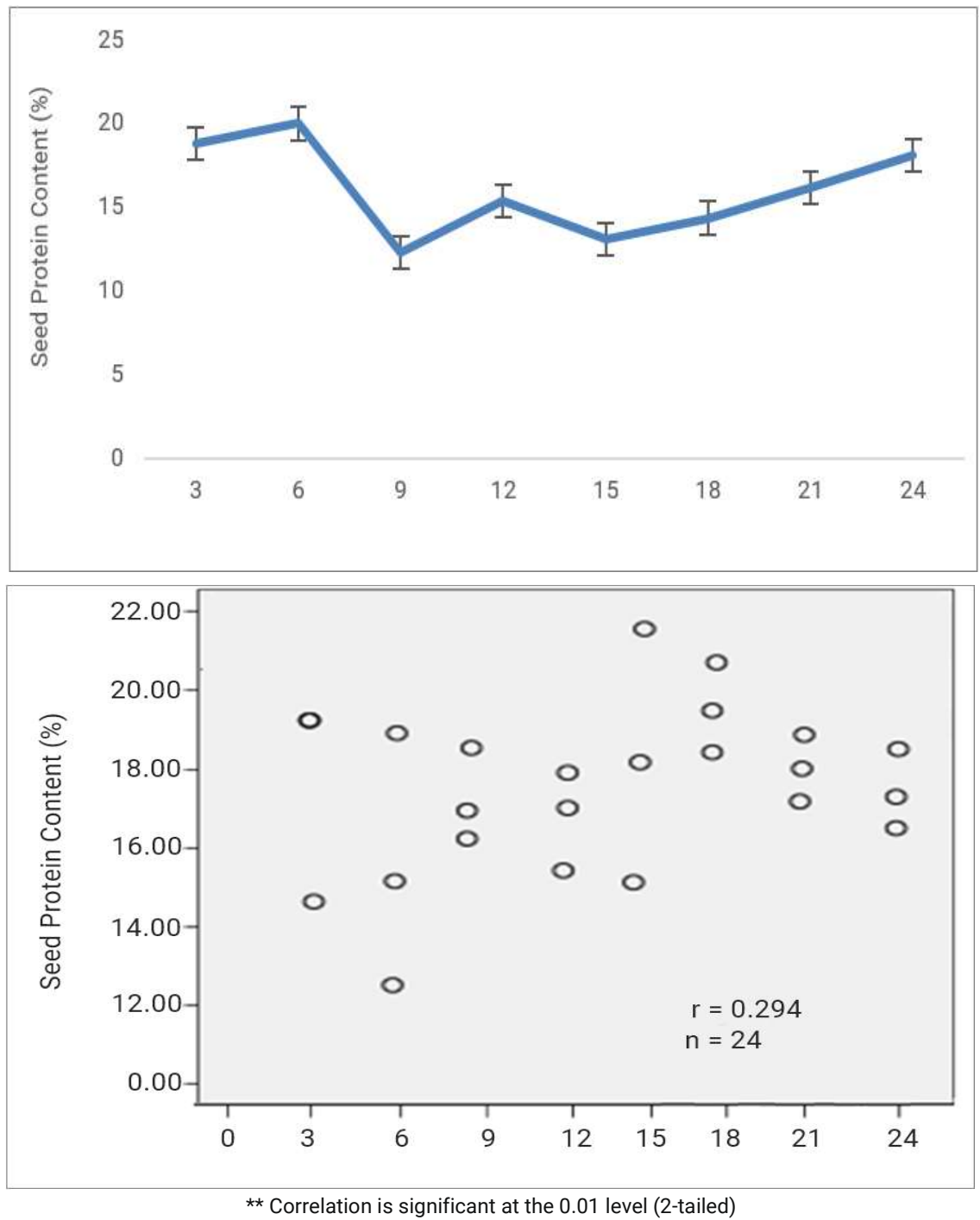

Figure $5 \mathrm{c}$. Changes in protein content of the okra fruit pericarp during development from the $3^{\text {rd }}$ to the $24^{\text {th }}$ DAA

\section{CONCLUSION}

During fruit development, chlorophyll and crude fiber content of the okra fruit pericarp increase with fruit age while sugar, starch and protein content decrease. 
Throughout seed development, sugar remained relatively low while starch and protein content remained high. For optimum fruit quality, okra fruits are best harvested as fresh green vegetable at 9 DAA. At this stage, the fruits are succulent, less fibrous and are rich in proteins and carbohydrates. Although much younger fruits have also high nutrient content, they are too small in size, and so harvesting them at this stage would not be practical and profitable.

\section{ACKNOWLEDGMENT}

The authors are grateful to the Philippines' Department of Science and Technology for providing the funds for this research.

\section{REFERENCES}

Brummel DA. 2013. Fruit growth, ripening and postharvest physiology. Plants in Action (2nd edn). Macmillan Education Australia Pty Ltd

Cachero T and Belonias BS. 2017. Morpho-anatomical and physiological changes of the lady finger (Abelmoschus esculentus (L.) Moench var. 'Smooth Green') fruit and seed during development. Science and Humanities Journal 11:40-63

Cagampang GB and Rodriquez FT. 1980. Methods of analysis for screening crops of appropriate qualities. IPB, University of the Philippines, Los Baños, Laguna

Cutler DF. 2007. Plant anatomy: an applied approach. Blackwell Publishing, UK

Johnson R. 2005. Biology. New York: McGraw Hill

Kim SK, Bae RN, Na H, Ko KD \& Chun C. 2003. Changes in the physicochemical characteristics during fruit development in june-bearing strawberry cultivars. Horticulture, Environment and Biotechnology 54:44-51

Kumar DS. 2012. A review on: Abelmoschus esculentus (Okra). International Research Journal of Pharmaceutical and Applied Sciences 3(4):129-132

Miccolis VI and Saltveit NDM Jr. 1991. Morphological and physiological changes during fruit growth and maturation of seven melon cultivars. Journal of the American Society of Horticultural Science 116(6):1025-1029

Patil SK and Shanmugasundaram S. 2015. Physicochemical changes during ripening of monthan banana. International Journal of Technology Enhancements and Emerging Engineering Research 3:18-21

Reece JB. 2014. Campbell Biology (10th edn). Pearson Education, Inc

Roy A, Shrivastava SL \& Mandal SM. 2014. Functional properties of Okra Abelmoschus esculentus L. (Moench): traditional claims and scientific evidences. Plant Science Today 1(3):121-130

Taiz L and ZeigerE. 2006. Plant physiology (3rd edn). McGraw Hill, New York

Umamahesh VD. 2005. Lecture notes on crop physiology. Acharya Ranga Agricultural University. Department of Plant Physiology, Agricultural College, Naira, India

Wu GL, Liu QL \& Da Silva JA. 2009. Ultrastructure of pericarp and seed capsule cells in the developing walnut (Juglans regia L.) fruit. South African Journal of Botany 75(1):128-136 